\title{
Determinan Nilai Perusahaan Sebelum dan pada Masa Pandemic COVID-19
}

\author{
Sri Ambarwati ${ }^{*}$, Tri Astuti², Salsabila Azzahra ${ }^{3}$ \\ 1,2,3 Progam Studi Akuntansi, Fakultas Ekonomi dan Bisnis \\ Universitas Pancasila \\ Jakarta 11480, Indonesia \\ sriambarwati@univpancasila.ac.id; triastuti@univpancasila.ac.id; \\ salsabilaazzahra@univpancasila.ac.id \\ *Correspondence: sriambarwati@univpancasila.ac.id
}

\begin{abstract}
This study aims to see the condition of companies in the consumer goods industry sector before the pandemic and during the pandemic using indicators such as Current Ratio, Debt to Equity Ratio (DER), Return on Assets (ROA), Return on Equity (ROE), Net Profit Margin (NPM) and company size against firm value. In the period before and during the Covid-19 PandemicThe method used in this research is quantitative method using secondary data from the company's financial statements for the first quarter until third quarter of 2019 and 2020 using regression method and different test Paired Sample t Test. . The results of this study indicate that (1) the Current Ratio before the Covid-19 pandemic had a significant negative effect on firm value, while Current The ratio during the Covid-19 pandemic did not have a significant effect on the firm value variable, (2) the Debt to Equity Ratio before the Covid-19 pandemic had a significant negative effect on the firm value variable, while the Debt to Equity Ratio during the Covid-19 pandemic had no significant effect on company value, (3) Return on Assets before and during the Covid-19 pandemic did not have a significant effect on the firm value variable, (4) Return on Equity before and during the Covid-19 pandemic had no significant effect on firm value, (5) Net Profit margin has a significant negative effect on firm value before and during pandemi Covid-19, and (6) company size has a significant positive effect on company value before and during the Covid-19 pandemic.
\end{abstract}

Keywords: Covid-19; Financial Ratio; Company Size; Price to Book Value.

\begin{abstract}
ABSTRAK
Penelitian ini bertujuan melihat kondisi perusahaan pada sektor industri Consumer Goods pada waktu sebelum pandemi dan pada saat pandemi menggunakan indikator Current Ratio, Debt to Equity Ratio (DER), Return on Asset (ROA), Return on Equity (ROE), Net Profit Margin (NPM) dan ukuran perusahaan terhadap nilai perusahaan. Pada periode sebelum dan masa Pandemic Covid-19. Metode yang digunakan pada penelitian ini adalah metode kuantitatif dengan menggunakan data sekunder dari laporan keuangan perusahaan Triwulan I sampai dengan III tahun 2019 dan 2020 menggunakan metode regresi dan uji beda Paired Sample t Test. Obyek dalam penelitian ini adalah perusahaan manufaktur sektor Consumer Goods yang terdaftar pada Bursa Efek Indonesia selama tahun 2019 dan 2020. Hasil penelitian ini menunjukkan bahwa (1) Current Ratio pada sebelum pandemi Covid-19 berpengaruh negatif signifikan terhadap nilai perusahaan, sedangkan Current Ratio pada masa pandemi Covid-19 tidak berpengaruh signifikan terhadap variabel nilai perusahaan, (2) Debt to Equity Ratio sebelum pandemi Covid-19 berpengaruh negatif signifikan terhadap variabel nilai perusahaan, sedangkan Debt to Equity Ratio pada masa pandemi Covid-19 tidak berpengaruh signifikan terhadap nilai perusahaan, (3) Return on Asset sebelum dan pada masa pandemi Covid-19 tidak berpengaruh signifikan terhadap variabel nilai perusahaan, (4) Return on Equity sebelum dan pada masa pandemi Covid-19 tidak berpengaruh signifikan terhadap nilai perusahaan, (5) Net Profit Margin berpengaruh negatif signifikan terhadap nilai perusahaan sebelum dan pada masa pandemi Covid-19, dan (6) ukuran perusahaan berpengaruh positif signifikan terhadap nilai perusahaan sebelum dan pada masa pandemi Covid-19. Hasil Uji beda Paired Sample t Test menunjukkan
\end{abstract}


bahwa perbedaan yang signifikan antara mean CR, DER, ROE, ROA dan NPM sebelum pandemi Covid-19 dengan mean CR, DER, ROE, ROA dan NPM pada saat pandemi Covid-19. Hal ini menunjukkan terjadi perbedaan kondisi perusahaan antara masa pandemi dan masa sebelum pandemi pada indikator variabel yang diteliti.

Kata Kunci: Covid-19; Rasio Keuangan; Ukuran perusahaan; Price to Book Value.

\section{PENDAHULUAN}

Di akhir Desember 2019, dunia dilanda oleh sebuah virus, yaitu Coronavirus Disease 2019 (COVID-19). Virus yang awalnya ditemukan di Wuhan, China memiliki penularan yang sangat cepat sehingga dalam waktu singkat, virus ini menyebar ke seluruh benua di dunia. Sejak pertama kali diumumkannya kasus pertama di Indonesia sebanyak dua kasus di Depok, tepatnya pada tanggal 2 Maret 2020. Sampai 3 Oktober 2020, sebanyak 34,6 juta orang terjangkit virus Covid-19 di dunia dan 1,03 juta jiwa meninggal akibat virus ini. Di Indonesia sendiri sudah 299.506 kasus positif dan 11.055 meninggal dunia.

Perkembangan pasar modal di Indonesia saat ini mengalami ketidakstabilan semenjak terjadinya pandemi Covid-19. Pasar modal di Indonesia menjadi salah satu negara yang mengalami penurunan yang cukup drastis. Perusahaan-perusahaan mulai dari sektor infrastruktur, pertanian, aneka industri, pertambangan dan yang lainnya sudah mulai melemah. Dampak pandemi Covid-19 menyebabkan aktivitas ekonomi dan operasional perusahaan menjadi terhambat yang berpengaruh di masa kini maupun di masa mendatang. Kondisi ini mempengaruhi perusahaan dan menghadapkan perusahaan pada situasi yang tidak pasti. Perusahaan dalam kelangsungan usahanya memiliki tujuan jangka pendek dan jangka panjang. Tujuan jangka pendek perusahaan, yaitu bertujuan untuk memperoleh laba secara maksimal dengan menggunakan sumber daya yang ada. Sementara dalam jangka panjang, tujuan utama perusahaan adalah memaksimalkan nilai perusahaan untuk memberikan kesejahteraan para pemegang saham. Memaksimalkan nilai perusahaan berarti memaksimalkan nilai sekarang dari semua keuntungan yang akan diterima oleh investor di masa yang akan datang atau berorientasi jangka panjang (Sudana, 2015:8). Karena nilai perusahaan berorientasi pada tujuan jangka panjang, maka setiap pengambilan keputusan atas kebijakan yang dilakukan perusahaan harus mempertimbangkan aspek lingkungan di sekitar perusahaan baik mikro dan makroekonomi. Penelitian ini bertujuan untuk mengetahui perbedaan pengaruh rasio keuangan dan ukuran perusahaaan sebelum dan pada masa pandemi Covid-19 pada perusahaan manufaktur sektor consumer good. Industri consumer goods merupakan industri yang strategis dalam kontribusinya terhadap perekonomian Indonesia. Dalam konteks global, potensi pasar consumer goods Indonesia tergolong cukup besar dan memiliki kontribusi terbesar kedua terhadap pembentukan Gross Domestic Product (GDP) setelah industri pertanian. Selain itu, dilihat dari sisi pengeluaran, GDP yang ditopang oleh pola konsumsi juga memiliki hubungan erat dengan industri ini. Pada masa pandemi kuartal dua (Q2) saat nilai Gross Domestic Product (GDP) di tingkat minus $5,2 \%$, market consumer goods saat itu masih relatif flat. Tapi konsumen industri pun tergerus mulai pada Q3. Gerai ritel baik modern maupun tradisional sepi pengunjung. walaupun pandemi membuat aktivitas belanja online mengalami peningkatan namun masih belum bisa menyamai nilai belanja offline dari pelanggan (Ridhoi, 2020). Berdasarkan analisis tersebut penelitian ini bertujuan melihat kondisi perusahaan pada sector industi Consumer goods pada waktu sebelum pandemi dan pada saat pandemi menggunakan indikator Current Ratio, Debt to Equity Ratio (DER), Return on Asset (ROA), Return on Equity (ROE), Net Profit Margin (NPM) dan ukuran perusahaan terhadap nilai perusahaan.

\section{Tinjauan Pustaka, Rumusan Hipotesis dan Rerangka Konseptual}

Penelitian ini berdasarkan teori Agency dan Teori Signaling. Menurut Anthony dan Govindarajan (2012:269), teori agensi adalah hubungan antara principal dan agent di mana diasumsikan bahwa setiap individu termotivasi oleh kepentingan dirinya sendiri sehingga menimbulkan konflik kepentingan antara principal dan agent. Signaling theory mengemukakan tentang bagaimana sebuah perusahaan memberikan sinyal kepada para pengguna laporan keuangan (Bringham dan Houston, 2014:184).

Tujuan perusahaan jangka panjang adalah memaksimalkan nilai perusahaan. Semakin tinggi nilai perusahaan maka semakin tinggi pula kesejahteraan para pemiliknya. Menurut Hery (2017:5) nilai perusahaan merupakan kondisi tertentu yang telah dicapai oleh suatu perusahaan sebagai gambaran dari kepercayaan masyarakat terhadap perusahaan setelah melalui suatu proses kegiatan selama beberapa tahun, yaitu mulai dari perusahaan tersebut didirikan sampai dengan saat ini. Pengukuran nilai perusahaan sangat perlu dilakukan untuk mengetahui bahwa suatu 
perusahaan mampu menunjukan kinerja yang baik dan dapat memberikan kemakmuran bagi para pemegang saham.

Rasio keuangan merupakan indeks yang menghubungkan dua angka akuntansi dan diperoleh dengan membagi satu angka dengan angka lainnya. Rasio keuangan digunakan untuk mengevaluasi kondisi keuangan dan kinerja perusahaan. Dari hasil rasio keuangan ini akan kelihatan kondisi kesehatan perusahaan yang bersangkutan. Current Ratio (CR) merupakan salah satu rasio likuiditas yang sering dijadikan penilaian oleh pemilik modal sebelum menginvestasikan dananya. Melalui current ratio investor dapat melihat seberapa banyak aktiva lancar yang tersedia untuk menutupi kewajiban jangka pendek yang segera jatuh tempo.

Debt to Equity Ratio (DER) merupakan rasio yang menunjukkan berapa besar utang atau kewajiban perusahaan dibandingkan dengan modalnya. Jika Debt to Equity Ratio (DER) suatu perusahaan itu tinggi maka dapat mencerminkan kinerja perusahaan tersebut dalam keadaan yang kurang baik. Return on Asset (ROA) yang tinggi menunjukkan bahwa dari total aktiva yang digunakan untuk beroperasi, perusahaan mampu memberikan laba bagi perusahaan. Sebaliknya, nilai Return on Asset (ROA) rendah menunjukkan bahwa dari total aktiva yang digunakan, perusahaan mendapatkan kerugian. Return on Asset dipakai untuk mengevaluasi apakah manajemen telah mendapat imbalan yang memadai (reasonable return) dari aset yang dikuasainya. Menurut Fahmi (2015:95), Return on Equity menunjukkan sejauh mana suatu perusahaan menggunakan sumber daya yang dimiliki agar mampu memberikan laba atas ekuitas. Return on Equity merupakan suatu perhitungan yang sangat penting pada perusahaan.

Menurut Hery (2016:227), Net Profit Margin menginterpretasikan tingkat efisiensi perusahaan, yaitu sejauh mana kemampuan perusahaan menekan biaya operasionalnya pada periode tertentu. Semakin tinggi nilai rasio ini, menunjukkan bahwa profibilitas perusahaan semakin baik sehingga investor tertarik untuk menanamkan modal (Mamduh, 2016:168). Nur'aini (2015) menyatakan bahwa ukuran perusahaan menggambarkan besar kecilnya suatu perusahaan yang tercermin dalam total aktiva atau total penjualan bersih. Besar kecilnya perusahaan sangat berpengaruh terhadap modal yang akan digunakan untuk operasionalnya, apalagi berkaitan dengan kemampuan perusahaan memeroleh tambahan modal dari dana eksternal ketika dana internal masih kurang untuk melakukan pembelanjaan.

Hipotesis dalam penelitian ini adalah sebagai berikut :

- Current Ratio (CR) berpengaruh terhadap Nilai Perusahaan sebelum dan pada masa pandemi Covid-19. Tingkat current ratio yang tinggi mencerminkan kecukupan kas sehingga semakin likuid suatu perusahaan maka tingkat kepercayaan investor akan meningkat. Hal ini akan meningkatkan citra perusahaan di mata investor sehingga dapat berpengaruh positif kepada nilai perusahaan (Annisa dan Chabachib, 2017). Penjelasan tersebut didukung oleh penelitian Putu dan Lestari (2016), yang menunjukkan bahwa current ratio berpengaruh positif signifikan terhadap nilai perusahaan.

- Debt to Equity Ratio (DER) berpengaruh terhadap Nilai Perusahaan sebelum dan pada masa pandemi Covid-19. Semakin meningkatnya Debt to Equity Ratio mengakibatkan profitabilitas perusahaan mengalami penurunan (Utami dan Prasetiono, 2016). Dalam penelitian Putri Utami dan Welas (2019), Debt to Equity Ratio memiliki pengaruh positif dan signifikan terhadap nilai perusahaan.

- Return on Asset (ROA) berpengaruh terhadap Nilai Perusahaan sebelum dan pada masa pandemi Covid-19. Return on asset menunjukkan semakin tinggi kinerja perusahaan dinilai oleh pemodal dengan dana yang telah ditanamkan di perusahaan. Menurut hasil penelitian Amanah (2018), Return on Asset (ROA) berpengaruh positif dan signifikan terhadap nilai perusahaan.

- $\quad$ Return on Equity (ROE) berpengaruh terhadap Nilai Perusahaan sebelum dan pada masa pandemi Covid-19. Return on Equity yang meningkat menyebabkan peningkatan permintaan terhadap saham dari perusahaan terkait sehingga nilai dari perusahaan pun ikut terdongkrak (Hamidy, dkk, 2015). Dari hasil penelitian Lumoly, dkk. (2018), Return on Equity memiliki pengaruh yang signifikan terhadap nilai perusahaan.

- Net Profit Margin (NPM) berpengaruh Terhadap Nilai Perusahaan

- Penelitian yang telah dilakukan oleh Apsari, dkk. (2015) dan Tikawati (2016) membuktikan bahwa Net Profit Margin (NPM) memiliki pengaruh positif dan signifikan terhadap nilai perusahaan. Sedangkan penelitian dari Lestari dan Armayah (2016) menyatakan bahwa net profit margin berpengaruh negatif dan signifikan terhadap nilai perusahaan. Namun, menurut Diharja (2017), net profit margin tidak berpengaruh terhadap nilai perusahaan. Berdasarkan uraian diatas, hipotesis yang dapat dirumuskan adalah: 
- Ukuran Perusahaan berpengaruh Terhadap Nilai Perusahaan.

- Penelitian yang dilakukan Ni Putu Ira Kartika Dewi \& Nyoman Abundanti (2019) membuktikan ukuran perusahaan berpengaruh positif signifikan terhadap nilai perusahaan. Hasil tersebut diperkuat oleh Arfin Taniman \& Jonnardi (2020), bahwa ukuran perusahaan berpengaruh positif signifikan terhadap nilai perusahaan. Hal ini berlawanan dengan Atika Suryandani (2018), yang menyatakan bahwa ukuran perusahaan berpengaruh negatif tidak signifikan terhadap nilai perusahaan.. Berdasarkan uraian diatas, hipotesis yang dapat dirumuskan adalah:

- Terdapat perbedaan rata-rata Current Ratio, Debt to Equity Ratio, Return on Asset, Return on Equity, Net Profit Margin dan Ukuran Perusahaan sebelum dan sesudah pandemi.

Dari uraian di atas kerangka pemikiran, adalah sebagai berikut:

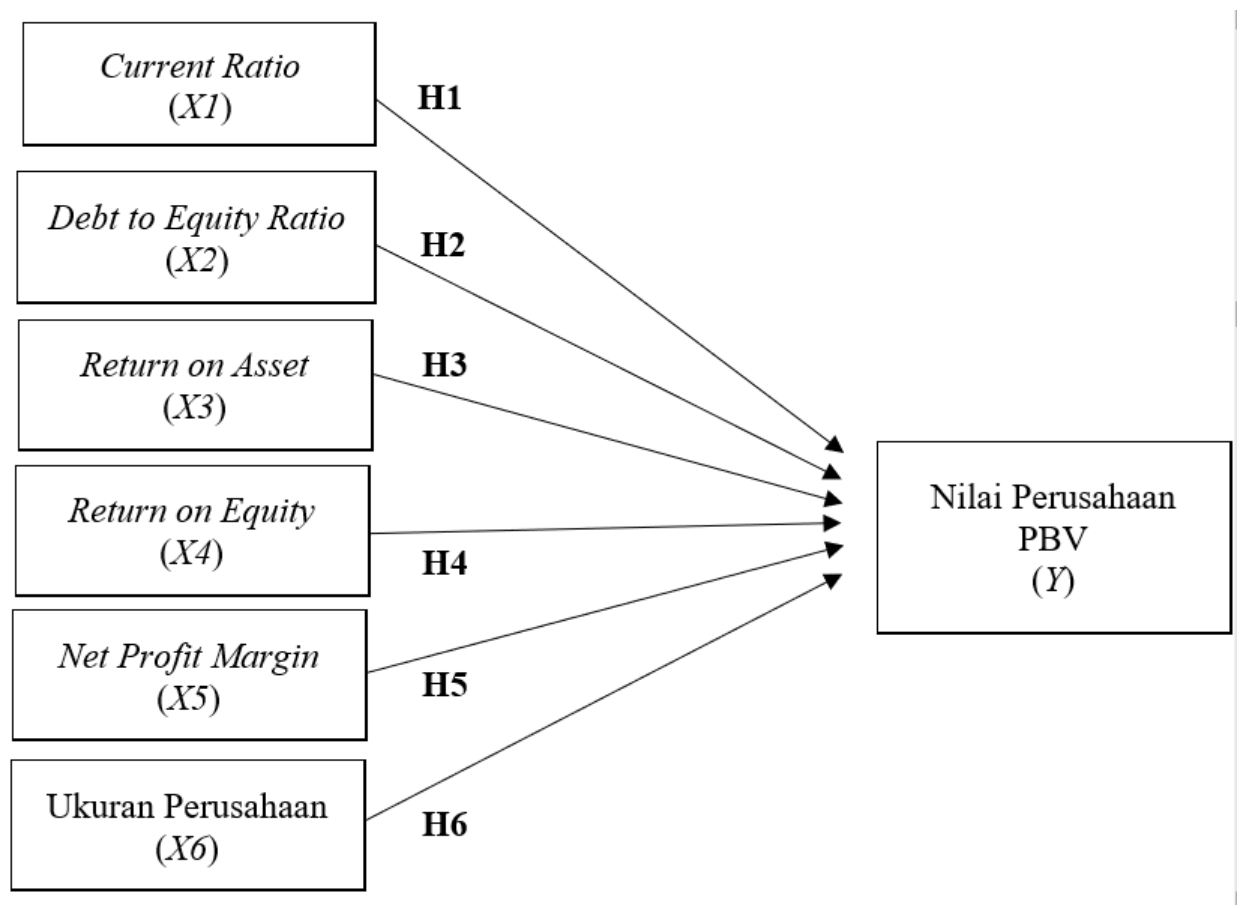

Gambar 1. Kerangka Pemikiran

\section{METODOLOGI PENELITIAN}

Dalam penelitian ini digunakan metode penelitian kuantitatif, deskriptif dan kausalitas komparatif. Populasi dalam penelitian ini adalah perusahaan manufaktur sektor consumer goods yang terdaftar pada Bursa Efek Indonesia selama tahun 2019 dan 2020. Industri consumer goods merupakan industri yang strategis dalam kontribusinya terhadap perekonomian Indonesia. Dalam konteks global, potensi pasar consumer goods Indonesia tergolong cukup besar dan memiliki kontribusi terbesar kedua terhadap pembentukan Gross Domestic Product (GDP) setelah industri pertanian. Selain itu, dilihat dari sisi pengeluaran, GDP yang ditopang oleh pola konsumsi juga memiliki hubungan erat dengan industri ini. Pada masa pandemi kuartal dua (Q2) saat nilai Gross Domestic Product (GDP) di tingkat minus 5,2\%, market consumer goods saat itu masih relatif flat. Tapi konsumen industri pun tergerus mulai pada Q3. Gerai ritel tempat penjualan baik modern maupun tradisional sepi pengunjung. walaupun pandemi membuat aktivitas belanja online mengalami peningkatan namun masih belum bisa menyamai nilai belanja offline dari pelanggan.

Metode sampling yang digunakan adalah teknik purposive sampling, metode ini dipilih dengan tujuan untuk mendapat sampel yang representatif sesuai kriteria yang ditentukan.

Adapun jumlah sampel sebanyak 86 dengan kriteria sampel yang akan digunakan adalah

Perusahaan yang digunakan dalam penelitian ini adalah perusahaan manufaktur sektor consumer goods, terdaftar di Bursa Efek Indonesia (BEI) dan mengeluarkan laporan keuangan triwulan I-III tahun 2019 dan 
triwulan I-III tahun 2020, memiliki data yang tersedia lengkap berupa laporan keuangan triwulan perusahaan yang diperlukan di dalam penelitian ini serta menggunakan mata uang rupiah dalam laporan keuangan perusahaan selama periode 2019-2020.

Teknik pengumpulan data dilakukan dengan cara menelusuri laporan keuangan triwulan perusahaan manufaktur sektor industri consumer goods yang go public di Bursa Efek Indonesia periode 2019-2020. Data diperoleh dengan cara mengumpulkan dan mengunduh data sekunder berupa laporan keuangan yang terdaftar di web Bursa Efek Indonesia (www.idx.co.id) atau web perusahaan yang bersangkutan.

Berikut uraian operasionalisasi variabel yan digunakan dalam penelitian ini:

Tabel 1. Operasionalisasi Variabel

\begin{tabular}{|c|c|c|c|c|}
\hline Variabel & Sub Variabel & Dimensi & Pengukuran & Skala \\
\hline \multirow{10}{*}{$\begin{array}{l}\text { Rasio } \\
\text { Keuangan }\end{array}$} & Rasio & Current & Current Asset & \multirow{2}{*}{ Rasio } \\
\hline & Likuiditas & Ratio & $\overline{\text { Current Liabilities }}$ & \\
\hline & Rasio & Debt to & Total Utang (Debt) & \multirow{2}{*}{ Rasio } \\
\hline & Leverage & $\begin{array}{l}\text { Equity } \\
\text { Ratio }\end{array}$ & $\overline{\text { Total Ekuitas (Equity) }}$ & \\
\hline & \multirow{6}{*}{$\begin{array}{l}\text { Rasio } \\
\text { Profitabili-tas }\end{array}$} & Return on & Earning After Interest \& Tax & \multirow{2}{*}{ Rasio } \\
\hline & & Asset & $\begin{array}{c}\text { Total Asset } \\
\end{array}$ & \\
\hline & & Return on & Earning After Interest \& Tax & \multirow{2}{*}{ Rasio } \\
\hline & & Equity & Total Equity & \\
\hline & & & Earning After Interest \& Tax & \multirow{2}{*}{ Rasio } \\
\hline & & & $\begin{array}{l}\text { Sales (Penjualan) } \\
\text { (P) }\end{array}$ & \\
\hline Ukuran & Ukuran & & \multirow{2}{*}{ LN(Total Asset } & \multirow{2}{*}{ Rasio } \\
\hline Perusahaan & Perusahaan & & & \\
\hline Nilai & & & Market price per share & \multirow{2}{*}{ Rasio } \\
\hline Perusahaan & & & $\overline{\text { Book value per share }}$ & \\
\hline
\end{tabular}

Sumber : diolah

HASIL DAN PEMBAHASAN

Tabel 2. Perbandingan Hasil Uji Statistik Deskriptif Triwulan I-III Tahun 2019 - 2020

\begin{tabular}{|c|c|c|c|c|c|c|c|c|c|}
\hline \multicolumn{10}{|c|}{ Descriptive Statistics } \\
\hline & \multirow{2}{*}{$N$} & \multicolumn{2}{|c|}{ Minimum } & \multicolumn{2}{|c|}{ Maximum } & \multicolumn{2}{|c|}{ Mean } & \multicolumn{2}{|c|}{ Std. Deviation } \\
\hline & & 2019 & 2020 & 2019 & 2020 & 2019 & 2020 & 2019 & 2020 \\
\hline$C R$ & 86 & 70,99 & 79,90 & 562,85 & 1307,42 & 235,53 & 285,53 & 135,67 & 269,02 \\
\hline$D E R$ & 86 & 15,63 & 12,44 & 246,80 & 257,29 & 91 & 98,08 & 60,77 & 68,45 \\
\hline$R O A$ & 86 & $-18,36$ & -63 & 50,97 & 69,75 & 10,85 & 7,83 & 14,06 & 17,17 \\
\hline$R O E$ & 86 & $-40,60$ & $-215,6$ & 69,86 & 85,9 & 17,46 & 10,19 & 23,19 & 37,35 \\
\hline$N P M$ & 86 & $-8,51$ & $-40,32$ & 36,43 & 26,99 & 5,54 & 3,54 & 7,67 & 11,45 \\
\hline$S I Z E$ & 86 & 25,45 & 23,99 & 31,91 & 32,26 & 28,63 & 28,69 & 1,53 & 1,62 \\
\hline$P B V$ & 86 &, 18 &, 14 & 8,88 & 6,75 & 2,15 & 1,66 & 1,80 & 1,55 \\
\hline
\end{tabular}

Valid N

(listwise)

Sumber: Hasil Pengolahan Data SPSS for windows versi 23.0, 2020 
Dari tabel di atas menunjukkan adanya penurunan nilai minimum, maksimum, mean dan standar deviasi pada Return on Asset (ROA), Return on Equity (ROE), Net Profit Margin (NPM), dan Price to Book Value (PBV) pada masa sebelum dan saat pandemi Covid-19. Namun sebaliknya dengan Current Ratio (CR), Debt to Equity Ratio (DER), dan ukuran perusahaan (Size) yang rata-ratanya terdapat kenaikan pada masa pandemi ini, hal ini dikarenakan pada masa pandemi perusahaan banyak mengalami peningkatan kewajiban perusahaan untuk melunasi hutang-hutangnya, hal ini menyebabkan CR dan DER meningkat. Adanya penurunan ROA, ROE, NPM, dan PBV terjadi akibat ketidakmampuan perusahaan dalam menghasilkan laba perusahaan yang tinggi selama masa pandemi Covid-19. Pada nilai CR mean bernilai sangat besar yaitu 235,53 dan 285,53 karena nilai asset lancar beberapa perusahaan sangat besar dibanding hutang lancar yang dimiliki yang menimbulkan excess liquidity dan kurang produktifnya aktiva lancar perusahaan.

Pada uji normalitas yang dilakukan, nilai Kolmogorof-Smirnov sebesar 0,062 (Sebelum masa pandemi Covid- 19) dengan tingkat signifikansi sebesar 0,200 (Sebelum masa pandemi Covid-19). Sedangkan nilai Kolmogorof-Smirnov pada masa pandemi Covid-19 sebesar 0,074 dengan tingkat signifikansi sebesar 0,200 (masa pandemi Covid-19). Karena nilai signifikan keduanya lebih besar dari 0,05 (sig $>\alpha)$, maka H0 diterima dan tolak Ha yang artinya data sebelum dan pada masa pandemi Covid-19 berdistribusi normal.

Pada uji autokorelasi model persamaan menunjukkan bahwa nilai Durbin-Watson (sebelum masa pandemi Covid-19) sebesar 1,903. Dengan jumlah data 86 dan terdapat sebanyak 6 variabel bebas, maka besar du adalah sebesar 1,8010. yang berarti data sebelum masa pandemi Covid-19 tidak terdapat autokorelasi. Sementara itu nilai Durbin-Watson pada saat pandemi Covid-19 sebesar 1,987. yang artinya data pada masa pandemi Covid-19 tidak terdapat autokorelasi.

Berdasarkan pengujian yang dilakukan menunjukkan bahwa semua variabel independen mempunyai nilai VIF $<10$ sehingga dapat disimpulkan bahwa model regresi data periode sebelum masa pandemi Covid-19 dan masa pandemi Covid-19 memiliki asumsi multikolinearitas yang terpenuhi (tidak terjadi multikolinearitas).

Pada pengujian ini menunjukkan bahwa pada variabel Current Ratio (CR), Debt to Equity Ratio (DER), Return on Asset (ROA), Return on Equity (ROE), Net Profit Margin (NPM), dan ukuran perusahaan (SIZE) sebelum dan pada masa pandemi Covid-19 memiliki nilai signifikansi lebih besar daripada 0,05. Sesuai dengan ketentuan yang menyatakan jika nilai signifikansi lebih besar dari 0,05 dapat diartikan data tidak terjadi heteroskedastisitas.

Tabel 3. Hasil Analisis Regresi Linear Berganda Triwulan I-III

Tahun $2019-2020$

\begin{tabular}{|c|c|c|c|c|c|c|c|}
\hline \multicolumn{4}{|c|}{ Unstandardized Coefficients } & \multirow{2}{*}{\multicolumn{2}{|c|}{$\begin{array}{c}\begin{array}{c}\text { Standardized } \\
\text { Coefficients }\end{array} \\
\text { Beta }\end{array}$}} & \multirow{2}{*}{\multicolumn{2}{|c|}{$t$}} \\
\hline \multicolumn{2}{|c|}{$B$} & \multicolumn{2}{|c|}{ Std. Error } & & & & \\
\hline 2019 & 2020 & 2019 & 2020 & 2019 & 2020 & 2019 & 2020 \\
\hline$-16,766$ & $-16,384$ & 5,532 & 5,977 & & & $-3,031$ & $-2,741$ \\
\hline,- 944 &,- 279 & ,206 & ,191 &,- 569 &,- 190 & $-4,585$ & $-1,462$ \\
\hline,- 508 &,- 167 & ,168 & ,188 &,- 392 &,- 129 & $-3,020$ &,- 886 \\
\hline,- 345 &,- 015 & ,248 &, 015 &,- 208 & ,253 & $-1,394$ & 1,008 \\
\hline ,091 & ,007 & , 189 & ,007 & ,067 &,- 260 & ,480 & $-1,044$ \\
\hline,- 518 &,- 651 & ,206 & ,213 &,- 238 &,- 356 & $-2,513$ & $-3,055$ \\
\hline 8,053 & 6,146 & 1,609 & 1,759 & ,457 &, 345 & 5,004 & 3,493 \\
\hline
\end{tabular}

Sumber: Hasil Pengolahan Data SPSS for windows versi 23.0, 2020

Berdasarkan tabel 3, model regresi berganda untuk periode sebelum masa pandemi Covid-19 dapat dirumuskan sebagai berikut:

$$
P B V=-16,766-0,944 C R-0,508 D E R-0,345 R O A+0,091 R O E-0,518 N P M+8,053 S I Z E+e
$$

Persamaan di atas dapat dijelaskan bahwa nilai konstanta -16,766 dengan signifikansi sebesar 0,003, artinya regresi linear ini signifikan untuk digunakan dalam model. Konstanta $-16,766$ berarti apabila CR, DER, ROA, ROE, NPM, dan SIZE konstan atau bernilai 0, maka besar PBV akan mengalami penurunan sebesar 16,766, sedangkan pada periode masa pandemi Covid-19 model regresi berganda dapat dirumuskan sebagai berikut:

$$
P B V=-16,384-0,279 C R-0,167 D E R+0,015 R O A-0,007 R O E-0,651 N P M+6,146 S I Z E+e
$$


Berdasarkan persamaan di atas dapat dijelaskan bahwa nilai konstanta -16,384 dengan signifikansi sebesar 0,008, artinya regresi linear ini signifikan untuk digunakan dalam model. Konstanta $-16,384$ berarti apabila CR, DER, ROA, ROE, NPM dan SIZE konstan atau bernilai 0, maka besar PBV akan mengalami penurunan sebesar 16,384 .

Hasil uji t, variabel current ratio sebelum pandemi Covid-19 berpengaruh negatif signifikan terhadap nilai perusahaan sebelum pandemi Covid-19, sedangkan current ratio pada masa pandemi Covid-19 tidak berpengaruh signifikan terhadap variabel nilai perusahaan. pada beberapa perusahaan yang menghasilkan rata-rata nilai current ratio yang terlalu tinggi memiliki kemungkinan perusahaan kurang efisien dalam menggunakan aset lancarnya untuk membayar hutang jangka pendeknya. Hasil penelitian pada sebelum pandemi Covid-19 ini mendukung penelitian Utami dan Welas (2019), yaitu bahwa current ratio memiliki pengaruh negatif signifikan terhadap nilai perusahaan. CR yang tinggi mengindikasikan adanya dana atau asset likuid yang menganggur sehingga akan mengurangi tingkat pendapatan perusahaan (Ardianto, 2017). Rendahnya tingkat pendapatan perusahaan menyebabkan kinerja keuangan perusahaan menurun yang berakibat pada menurunnya nilai perusahaan. Sedangkan hasil penelitian pada masa pandemi Covid-19 ini juga menunjukkan bahwa current ratio tidak memiliki pengaruh yang signifikan terhadap nilai perusahaan. Pada masa pandemi sampai dengan triwuln ke 3 berdasarkan data yang diperoleh, perusahaan mulai banyak menambah nilai hutang dan mengalami penurunan pada assetnya namun tidak semua perusahaan mengalami fenomena ini karena masih ada perusahaan yang dapat bertahan sehingga trend dari pergerakan asset dan hutang lancar tidak dapat diprediksi arahnya secara seragam, hasil current ratio tidak memiliki pengaruh yang signifikan terhadap nilai perusahaan. mendukung temuan Selin Lumoly, dkk (2018).

Variabel debt to equity ratio sebelum pandemi Covid-19 berpengaruh negatif signifikan terhadap variabel nilai perusahaan, sedangkan debt to equity ratio pada masa pandemi Covid-19 terbukti tidak berpengaruh signifikan terhadap nilai perusahaan. Sebelum masa pandemi , sebagian besar perusahaan akhirnya memilih hutang sebagai alternatif pendanaan. Penggunaan hutang yang besar cukup berbahaya sehingga perusahaan dapat mengalami kesulitan dalam menjaga stabilitas arus kasnya yang dapat membawa penurunan nilai perusahaan. Pada masa pandemi dari data yang diperoleh ada beberapa perusahaan yang melonjak tajam meningkatkan hutang non lancarnya, dapat terjadi karena tekanan pada awal masa pandemi sedangkan rata-rata perusahaan lain di dalam sampel masih mengalami kondisi yang stabil. Aspek psikologis kekhawatiran tidak mampunya melunasi piutang dapat menyebabkan perusahaan tidak menggantungkan tambahan dana dari hutang, dan berusaha mencari strategi yang lain, sehingga memberikan kemungkinan ratio DER tidak memiliki pengaruh yang signifikan pada masa pandemi.

Variabel ROA sebelum pandemi Covid-19 tidak berpengaruh signifikan terhadap variabel nilai perusahaan. Pada masa pandemi Covid-19, terbukti juga tidak berpengaruh signifikan terhadap variabel nilai perusahaan. Penurunan nilai rata-rata return on asset mengindikasikan bahwa perusahaan kurang efisien dalam memanfaatkan asetnya untuk memeroleh laba. Return on asset tidak berpengaruh terhadap nilai perusahaan disebabkan pada periode sebelum dan pada masa pandemi Covid-19 kemungkinan yang terjadi adalah peningkatan aset yang dimiliki tanpa diikuti dengan peningkatan laba sehingga pemegang saham memandang bahwa kinerja perusahaan kurang efektif dalam menggunakan asetnya. peningkatan aset tidak sebanding dengan peningkatan laba, fenomena ini bertambah terutama pada kondisi pada saat pandemi.Hasil penelitian ini sejalan dengan penelitian yang dilakukan Kurniasari dan Wahyuati (2017) dan Utami dan Welas (2019) yang menyatakan bahwa return on asset tidak berpengaruh signifikan terhadap nilai perusahaan.

Variabel Return on Equity sebelum pandemi Covid-19 menunjukkan tidak terdapatnya pengaruh ROE secara signifikan terhadap nilai perusahaan, sedangkan pada masa pandemi Covid-19, terbukti juga tidak berpengaruh signifikan terhadap nilai perusahaan. Return on equity tidak mempunyai pengaruh terhadap nilai perusahaan disebabkan pada sebelum dan khususnya saat pandemi Covid-19 perusahaan memiliki nilai ekuitas yang besar, tetapi tidak dioptimalisasi untuk menghasilkan laba yang besar terlebih pada masa pandemi Covid-19 perusahaan mengalami penurunan penjualan perusahaan sehingga margin laba yang dihasilkan rendah. Hasil penelitian ini mendukung penelitian yang dilakukan Ulfa dan Asyik (2020) yang menyatakan return on equity tidak berpengaruh signifikan terhadap nilai perusahaan.

Hasil uji t pada variabel net profit margin sebelum pandemi Covid-19 menunjukkan terdapatnya pengaruh negatif signifikan terhadap variabel nilai perusahaan, sedangkan pada masa pandemi Covid-19, terbukti juga berpengaruh negatif signifikan terhadap variabel nilai perusahaan. Artinya semakin tinggi margin yang ditetapkan perusahaan maka nilai marjin akan makin menurun. Margin kotor yang tinggi pada dasarnya akan berdampak pada harga jual produk atau jasa perusahaan yang semakin mahal. Fakta tersebut justru menjadi alasan investor 
tidak ingin harga jual produk perusahaan ditetapkan tinggi karena dalam jangka panjang akan mempengaruhi daya saing perusahaan (Lestari dan Armayah :2016), terlebih di masa pandemi dimana daya beli konsumen menurun sehingga lebih sensitif terhadap kenaikan harga.

Hasil uji t pada ukuran perusahaan sebelum pandemi Covid-19 menunjukkan bahwa ukuran perusahaan berpengaruh positif signifikan terhadap nilai perusahaan, sedangkan pada masa pandemi Covid-19, terbukti juga berpengaruh positif signifikan terhadap variabel nilai perusahaan. Ukuran perusahaan yang tinggi berpengaruh menyebabkan nilai perusahaan juga akan semakin tinggi. Pada masa pandemi Covid-19 ini perusahaan besar cenderung memiliki kondisi perusahaan yang lebih stabil. Kondisi ini menyebabkan naiknya nilai perusahaan dan membuat para investor memiliki ekspektasi yang besar pada perusahaan besar. Ukuran perusahaan yang besar mencerminkan bahwa perusahaan tersebut sedang mengalami perkembangan dan pertumbuhan yang baik sehingga meningkatkan nilai dari suatu perusahaan.. Semakin besar aset yang dimiliki maka perusahaan dinilai mandiri dan kondisi keuangan yang likuid (Norvaišienė \& Stankevičienė, 2014). Pada masa pandemi perusahaan berukuran besar cenderung memiliki asset dan sumber modal yang besar dan stabil sehingga dapat bertahan mempertahankan kinerjanya dibanding perusahaan dengan ukuran kecil.

Pada hasil pengujian $\mathrm{F}$ dapat disimpulkan bahwa Ho diterima, karena $\mathrm{F}$ hitung $>\mathrm{F}$ tabel dan signifikansi $0,000<0,05$, yang berarti bahwa nilai signifikansi sebesar $0,000 \mathrm{~b}<0,05$ menunjukkan bahwa model regresi layak digunakan untuk penelitian.

Pada periode masa pandemi Covid-19 hasil uji F memperlihatkan nilai F hitung sebesar 6,489 dan signifikansi 0,000. Hasil uji $\mathrm{F}$ dapat disimpulkan Ho diterima karena $\mathrm{F}$ hitung $>\mathrm{F}$ tabel dan signifikansi $0,000<0,05$, yang berarti nilai signfahmiifikansi sebesar $0,000 \mathrm{~b}<0,05$ menunjukkan bahwa model regresi layak digunakan untuk penelitian.

Koefisien determinasi (Adjusted $\mathrm{R}^{2}$ ) yang terlihat pada tabel 5 mengindikasikan kemampuan persamaan regresi berganda untuk menunjukkan tingkat penjelasan variabel independen terhadap variabel dependen. Besarnya koefisien determinasi (Adjusted $\mathrm{R}^{2}$ ) adalah 0,955 atau 95,5\% ini berarti bahwa kemampuan variabel independen yakni variabel Current Ratio (CR), Debt to Equity Ratio (DER), Return on Asset (ROA), Return on Equity (ROE), Net Profit Margin (NPM), dan ukuran perusahaan (SIZE) memiliki kontribusi pengaruh terhadap variabel Nilai Perusahaan sebesar 95,5\%, sedangkan sisanya yaitu sebesar 4,5\% (100\% - 95,5\%) dipengaruhi oleh faktor-faktor lain di luar penelitian.

Koefisien determinasi (Adjusted R2) pada masa pandemi Covid-19 tabel 4.10 sebesar 0,96 atau 96\%, ini berarti bahwa kemampuan variabel Current Ratio (CR), Debt to Equity Ratio (DER), Return on Asset (ROA), Return on Equity (ROE), Net Profit Margin (NPM), dan ukuran perusahaan (SIZE) pada saat pandemi Covid-19 memiliki kontribusi pengaruh terhadap variabel nilai perusahaan sebesar $96 \%$, sedangkan sisanya yaitu sebesar $4 \%(100 \%$ - 96\%) dipengaruhi oleh faktor-faktor lain di luar penelitian.

Tabel 4. Paired Samples Test

\begin{tabular}{|c|c|c|c|c|c|c|c|c|c|}
\hline & & \multicolumn{5}{|c|}{ Paired Differences } & \multirow{3}{*}{$\mathbf{t}$} & \multirow{3}{*}{ df } & \multirow{3}{*}{$\begin{array}{c}\text { Sig. } \\
\text { (2-tailed) }\end{array}$} \\
\hline & & \multirow[t]{2}{*}{ Mean } & \multirow{2}{*}{$\begin{array}{c}\text { Std. } \\
\text { Deviation }\end{array}$} & \multirow{2}{*}{$\begin{array}{l}\text { Std. Error } \\
\text { Mean }\end{array}$} & \multicolumn{2}{|c|}{$\begin{array}{l}95 \% \text { Confidence Interval } \\
\text { of the Difference }\end{array}$} & & & \\
\hline & & & & & Lower & Upper & & & \\
\hline Pair 1 & $\begin{array}{l}\text { CRpre - } \\
\text { CRin }\end{array}$ & -49.99485 & 202.98146 & 21.88805 & -93.51416 & -6.47553 & -2.284 & 85 & .025 \\
\hline Pair 2 & $\begin{array}{l}\text { DERpre - } \\
\text { DERin }\end{array}$ & -7.08421 & 31.64576 & 3.41245 & -13.86907 & -.29935 & -2.076 & 85 & .041 \\
\hline Pair 3 & $\begin{array}{l}\text { ROEpre - } \\
\text { ROEin }\end{array}$ & 7.27045 & 25.56887 & 2.75716 & 1.78848 & 12.75243 & 2.637 & 85 & .010 \\
\hline Pair 4 & $\begin{array}{l}\text { ROApre - } \\
\text { ROAin }\end{array}$ & 3.02236 & 10.89477 & 1.17481 & .68652 & 5.35820 & 2.573 & 85 & .012 \\
\hline Pair 5 & $\begin{array}{l}\text { NPMpre - } \\
\text { NPMin }\end{array}$ & 1.99980 & 8.30253 & .89529 & .21974 & 3.77987 & 2.234 & 85 & .028 \\
\hline Pair 6 & $\begin{array}{l}\text { SIZEpre - } \\
\text { SIZEin }\end{array}$ & -.05690 & .23722 & .02558 & -.10776 & -.00604 & -2.224 & 85 & .029 \\
\hline Pair 7 & $\begin{array}{l}\text { PBVpre - } \\
\text { PBVin }\end{array}$ & .49163 & .73818 & .07960 & .33336 & .64989 & 6.176 & 85 & .000 \\
\hline
\end{tabular}

Sumber: Hasil Pengolahan Data SPSS for windows versi 23.0, 2020 
Berdasarkan pengujian uji beda dua sampel berpasangan diatas dapat dilihat bahwa nilai signifikansi CR adalah 0,025, DER adalah 0,041, ROE adalah 0,010, ROA adalah 0,012, NPM adalah 0,028 dan Size adalah 0,029 . Hal ini menunjukkan bahwa nilai signifikansi uji $\mathrm{T}$ dari semua variabel $<0,05$ sehingga $\mathrm{H} 1$ di terima, yang artinya terdapat perbedaan yang signifikan antara mean CR, DER, ROE, ROA dan NPM sebelum pandemi Covid-19 dibandingkan dengan mean CR, DER, ROE, ROA dan NPM pada saat pandemi Covid-19.

Bila dibandingkan dengan hasil pengujian regresi, perbedaan hasil sebelum dan sesudah pandemic hanya terjadi pada variabel Current Ratio (CR) dan Debt to Equity Ratio (DER), dimana Current Ratio pada sebelum pandemi Covid-19 berpengaruh negatif signifikan terhadap nilai perusahaan, sedangkan pada masa pandemi tidak berpengaruh secara signifikan, demikian juga pada variabel Debt to Equity Ratio sebelum pandemi Covid-19 berpengaruh negatif signifikan terhadap variabel nilai perusahaan, sedangkan Debt to Equity Ratio pada masa pandemi Covid-19 tidak berpengaruh signifikan terhadap nilai perusahaan.

Perbedaan ini terjadi karena tujuan dari kedua pengujian di atas memang berbeda, atau kemungkinan dapat disimpulkan bahwa perbedaan mean yang membawa perubahan besar hanya terjadi pada variabel $\mathrm{CR}$ dan DER yang membawa pada perubahan pada hasil uji regresi sebelum dan sesudah masa Pandemic Covid 19 menunjukkan terjadi perbedaan kondisi perusahaan antara masa pandemi dan masa sebelum pandemi pada indikator variabel yang diteliti.

\section{KESIMPULAN}

\section{Simpulan}

Simpulan yang dapat diperoleh dari penelitian ini adalah:

- Variabel current ratio pada sebelum pandemi Covid-19 berpengaruh negatif signifikan terhadap nilai perusahaan sebelum pandemi Covid-19, sedangkan current ratio pada masa pandemi Covid-19 tidak berpengaruh signifikan terhadap variabel nilai perusahaan. Nilai rata-rata current ratio pada masa pandemi Covid-19 mengalami kenaikan. Semakin tingginya nilai current ratio menunjukkan bahwa semakin tinggi pula perusahaan dana menganggur yang dikelola perusahaan.

- Variabel debt to equity ratio sebelum pandemi Covid-19 berpengaruh negatif signifikansi terhadap variabel nilai perusahaan, sedangkan debt to equity ratio pada masa pandemi Covid-19 tidak berpengaruh signifikan terhadap nilai perusahaan. Nilai rata-rata debt to equity ratio pada masa pandemi Covid-19 mengalami kenaikan. Semakin tinggi debt to equity ratio yang dimiliki perusahaan maka akan semakin tinggi pengaruhnya terhadap nilai perusahaan. Penggunaan hutang yang terlalu tinggi akan membahayakan perusahaan, tetapi pada beberapa perusahaan yang meningkatkan hutang dapat dipandang sebagai perusahaan yang yakin dengan prospek perusahaan di masa yang akan datang.

- Variabel return on asset sebelum dan pada masa pandemi Covid-19 tidak berpengaruh signifikan terhadap variabel nilai perusahaan. Nilai rata-rata Return on Asset pada masa pandemi Covid-19 mengalami penurunan. Penurunan ini menunjukkan perusahaan kurang efisien dalam memanfaatkan asset untuk meperoleh laba.

- Variabel return on equity tidak berpengaruh signifikan terhadap nilai perusahaan sebelum dan pada masa pandemi Covid-19. Nilai rata-rata Return on Equity pada masa pandemi Covid-19 mengalami penurunan. Penurunan ini dipengaruhi oleh menurunya tingkat pengembalian aktiva. Hal tersebut menunjukkan bahwa perusahaan tidak dapat memaksimalkan ekuitas untuk menaikkan laba perusahaan.

- Variabel net profit margin berpengaruh negatif signifikan terhadap nilai perusahaan sebelum dan pada masa pandemi Covid-19. Nilai rata-rata net profit margin pada masa pandemi Covid-19 mengalami penurunan. Semakin rendah net profit margin mengindikasikan bahwa operasi penjualan suatu perusahaan rendah atau perusahaan belum mampu mengelola penjualannya untuk menghasilkan laba yang tinggi.

- Variabel ukuran perusahaan berpengaruh positif signifikan terhadap nilai perusahaan sebelum dan pada masa pandemi Covid-19. Nilai rata-rata ukuran perusahaan pada masa pandemi Covid-19 mengalami kenaikan. Besarnya ukuran suatu perusahaan memengaruhi nilai perusahaan. Perusahaan yang berskala besar cenderung akan menarik minat investor karena akan berimbas dengan nilai perusahaan. 
- Terdapat perbedaan yang signifikan antara mean CR, DER, ROE, ROA dan NPM sebelum pandemi Covid-19 dibandingkan dengan mean CR, DER, ROE, ROA dan NPM pada saat pandemi Covid-19 menunjukkan terjadi perbedaan kondisi perusahaan antara masa pandemi dan masa sebelum pandemi pada indikator variabel yang diteliti.

\section{Implikasi Manajerial}

Dengan menganalisis kondisi perekonomian yang masih dilanda pandemi, perusahaan diharapkan dapat menggunakan dan mengoptimalkan dan asset yang ada untuk menopang operasional usaha. Diharapkan perusahaan mampu meningkatkan pemberdayaan sumber daya yang ada, baik secara efektif maupun efisien dalam rangka menghadapi kondisi pandemi. Perusahaan diharapkan pula dapat melakukan perubahan operasional serta mencari ide baru untuk dapat tetap mempertahankan usaha dengan keadaan pandemi Covid-19 karena kondisi yang diprediksi masih belum menunjukkan tanda bahwa perekenomian dalam waktu dekat dapat terlepas dari efek pandemic Covid-19.

\section{Keterbatasan Penelitian}

Pada saat melakukan penelitian dilakukan bulan September-Nopember 2020 sehingga mengalami kendala karena data triwulan 4 belum diterbitkan. Imbas terhadap industri berdasarkan media juga mulai terasa di Q2. kuartal dua (Q2) itu Gross Domestic Product (GDP) secara makro menghadapi tantanganan minus 5,2\%, sehingga efek pandemic-19 diharapkan mulai dapat diamati pada period sampai dengan triwulan ke 3.

\section{DAFTAR PUSTAKA}

Amanah, L. (2018). Pengaruh Kinerja Keuangan Terhadap Nilai Perusahaan Dengan Pengungkapan Corporate Social Responsibility Sebagai Variabel Pemoderasi. Jurnal Ilmu dan Riset Akuntansi. Volume 7 (11).

Annisa, R., Chabachib, M. (2017). Analisis Pengaruh Current Ratio, Debt to Equity, Return on Asset Terhadap Price to Book Value dengan Dividen Payout Ratio Sebagai Variabel Intervening Pada Perusahaan Industri Manufaktur Yang Terdaftar Di BEI Periode 2011-2014. Diponogoro Jurnal of Management. Volume $6(1)$.

Ardianto, M. J., Chabachib, M., \& Mawardi, W. (2017). Pengaruh Kepemilikan Institusional, DER, ROA, Dan Current Ratio Terhadap Nilai Perusahaan Dengan Kebijakan Dividen Sebagai Variabel Intervening (Studi Pada Perusahaan Manufaktur Di BEI Periode Tahun 2011-2015) (Doctoral dissertation, Diponegoro University).

Brigham, E. F., Gapenski, L. C. \& Daves, P. R. (2011). Intermediate financial management.9th Edition. Florida: Dryden Press.Fahmi, I. (2015). Manajemen Investasi Teori dan Soal Jawab. Jakarta: Salemba Empat.

Devi, S., Warasniasih, N. M. S., Masdiantini, P. R., \& Musmini, L. S. (2020). The Impact of COVID-19 Pandemic on the Financial Performance of Firms on the Indonesia Stock Exchange. Journal of Economics, Business, \& Accountancy Ventura, 23(2), 226-242.

Hamidy, R.R., Wiksuana, I.G.B., Artin L.G.S. (2015). Pengaruh Struktur Modal Terhadap Nilai Perusahaan Dengan Profitabilitas Sebagai Variabel Intervening Pada Perusahaan Property and Real Estate and Property Di Bursa Efek Indonesia. E-Jurnal Ekonomi dan Bisnis Universitas Udayana. Volume 4 (10).

Hery. (2017). Kajian Riset Akuntansi. Cetakan Pertama. Jakarta: PT Grasindo.

Kurniasari, M.P., Wahyuati, A. (2017). Pengaruh Profitabilitas, Rasio Aktivitas, dan Laverage Terhadap Nilai Perusahaan Pada Perusahaan Manufaktur Yang Terdaftar Di BEI. Jurnal Ilmu dan Riset Manajemen. Volume 6 (8).

Lestari, S. A., Armayah, M. (2016). Profitability and Company Value: Empirical Study of Manufacture Companies in Indonesia Period 2009 - 2014. Information Management and Business Review. Volume 8 (3). Hal: 6-10. 
Lumoly, S., Murni, S., Untu, V.N. (2018). Pengaruh Likuiditas, Ukuran Perusahaan Dan Profitabilitas Terhadap Nilai Perusahaan (Studi Pada Perusahaan Logam Dan Sejenisnya Yang Terdaftar Di Bursa Efek Indonesia). Jurnal Emba. Volume 6 (3).

Norvaišienė, R., \& Stankevičienė, J. (2014). Impact of companies' internal factors on stock liquidity in Baltic markets. Procedia-Social and Behavioral Sciences, 156, 543-547.

Nur'aini, I. (2015). Pengaruh Pertumbuha Perusahaan, Ukuran Perusahaan Dan Profitabilitas Terhadap Nilai Perusahaan Dengan Struktur Modal Sebagai Variabel Intervening Studi Empiris pada Perusahaan Manufaktur yang Terdaftar diBursa Efek Indonesia Tahun 2010-2014. Skripsi. Fakultas Ekonomi dan Bisnis. Yogyakarta: Universitas Muhammadiyah Yogyakarta.

Primadita, A., \& Haryono, N. A. (2021). Dinamika Bisnis Selama Pandemi Covid-19 pada Tingkat Likuiditas Perusahaan Pertanian dan Consumer Goods di Indonesia. Business Management Analysis Journal (BMAJ), 4(1), 97-120

Ridhoi, M. A. (2020). Industri-industri Potensial di Tengah Kontraksi Ekonomi. Katadata.Co.Id. Diakses dari: https://katadata.co.id/muhammadridhoi/indepth/5f2ca2767ab84/industri-industri potensial-di-tengah-kontraksi-ekonomi

Sarngadharan, M. \& Rajitha, K. S. (2011). Financial Analysis of Management Decision. New Delhi: PHI Learning Private Limited

Sudana, I.M. (2015). Manajemen Keuangan Perusahaan: Teori dan Praktik. Edisi 2. Jakarta: Penerbit Erlangga.

Ulfa, R., Asyik, N.F. (2018). Pengaruh Kinerja Keuangan Terhadap Nilai Perusahaan Dengan Good Corporate Governance Sebagai Variabel Moderasi. Jurnal Ilmu dan Riset Akuntansi. Volume 7 (10).

Utami, P., Welas. (2019). Pengaruh Current Ratio, Return On Asset, Total Asset Turnover Dan Debt To Equity Ratio Terhadap Nilai Perusahaan (Studi Empiris pada Perusahaan Manufaktur Sub Sektor Properti dan Real Estate Yang Terdaftar di Bursa Efek Indonesia Periode 2015-2017). Jurnal Akuntansi dan Keuangan. Volume 8 (1).

Zulfitra, Z., \& Tumanggor, M. (2020). Reaksi Pasar Modal Index LQ45, Index Consumer Goods, Index Manufacture dan Index Finance pada Peristiwa Pandemi Covid-19 April 2020 di Indonesia. Jurnal Semarak, $3(3), 1-10$ 